\title{
INFLATION AND MONETARY POLICY IN RUSSIA IN SEPTEMBER 2015
}

\author{
A.Bozhechkova
}

The Consumer Prices Index (CPI) in September continued to see its growth rates increase, $0.6 \%$ up $10.7 \%$ up in September 2014). The Russian ruble saw a much slower depreciation in September-October, compared to August, due to some rallies in the oil market. For the first time in five years, banks and enterprises saw their net capital outflow in Q3 2015 as a result of a substantial decline in foreign assets which were used to repay their foreign loans, and also due to the fact that individuals sold foreign exchange in cash.

The increase in prices in August-September 2015 was primarily accounted for by a substantial depreciation of the ruble which hit, in response to slumping oil prices, the level reached earlier in the year. The growth rate of the Consumer Prices Index (CPI) in September 2015 gained 0.6\% (0.4\% up in August 2015), 15.7\% up compared to the same period of 2014, 0.1 p.p. down compared to the previous month (August) value (Fig. 1).

The Core Consumer Prices Index in September stood at $100.8 \%$, and it kept being higher than the CPI. It should be noted that this situation is explained by the fact that the shopping (consumer) baskets of items making up the Consumer Prices Index and the Core Consumer Prices Index differ in sensitivity to the national currency devaluation. Traditionally, the ruble's depreciation tends to lead to a much higher increase in prices of marketable goods, most of which are used for calculating the core $\mathrm{CPI}$, compared to nonmarketable goods which comprise a substantial share of the basket for calculating the CPI.

In September, prices of food products saw further increase following the three months of deflation. In September, the Consumer Prices Index for food products stood at $100.4 \%$ ( $99.3 \%$ in August). The following food products saw an increase in prices: the price of sunflower oil increased 5.2\% (1.5\% in August 2015), eggs $4.9 \%$ (down $0.2 \%$ in August). It should be noted that the increase in sunflower oil prices was triggered by favorable conditions in the global vegetable oil market and a reduction in yields per hectare due to the last summer's hot weather in some of the regions in Russia. Prices of fruits and vegetables kept falling, showing a negative price growth rate of $-2.3 \%$ (9.8\% down in August).

Prices in the group of non-food products increased in September $1.1 \%$ (0.8\% up in August). The following non-food products saw marked price growth rate in September due to the ruble's depreciation since May till August 2015, when the highest value was reached: electric products and other house appliances (from 1.0\% in August to $1.9 \%$ in September), clothes (from $0.8 \%$ in August to $1.5 \%$ in September), footwear (from $0.9 \%$ in
August to $1.9 \%$ in September), knitted wear (from 0.8\% in August to $1.5 \%$ in September).

Prices and tariffs of paid services to individuals in September remained the same. The traditional growth in prices of education series in September (104.9\% up) was offset by a seasonal decline in prices of sanatorium and health-improving services (95.9\%), outbound tourism services (97.3\%). Additionally, prices of passenger transport services saw a decline (97.6\%) (Fig. 2).

The median value of the anticipated twelve-month inflation has increased from $14.8 \%$ in August to $16 \%$ in September, according to a survey which is conducted by OOO INFORM (a limited liability company) and pub-

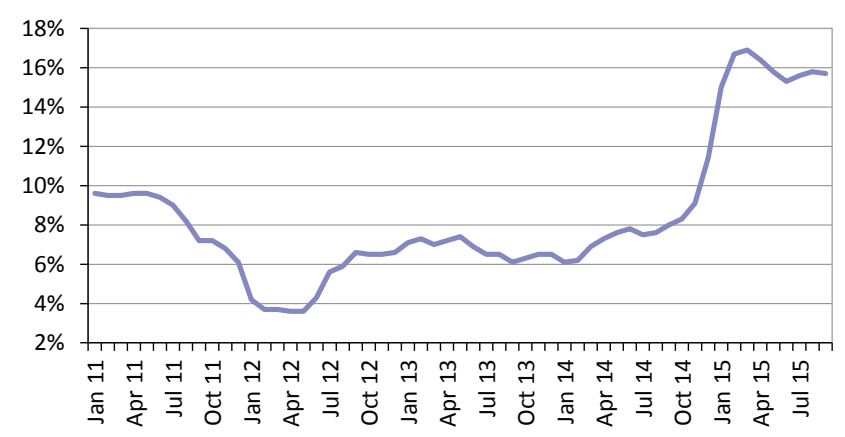

Source: The Federal State Statistic Service of Russia (Rosstat). Fig. 1. CPI growth rate in 2011 to 2015 (YOY percentage change)

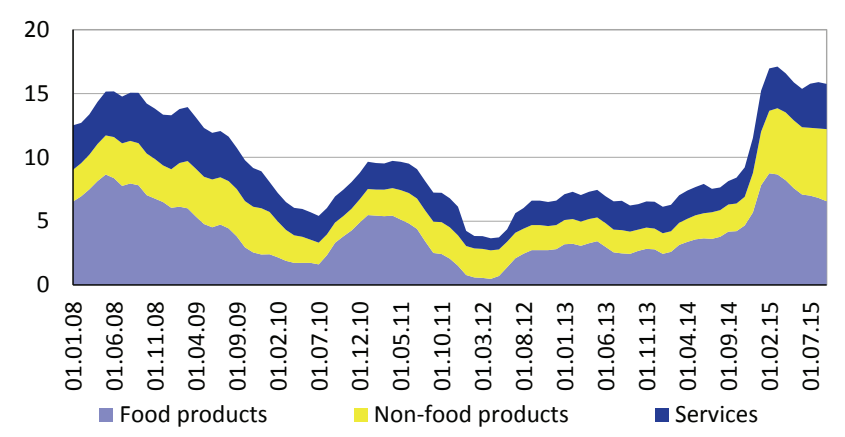

Source: Rosstat.

Fig. 2. The contribution of the key components to the CPI on a year-over-year basis in 2008 to 2015 
lished monthly by the Bank of Russia. It is our opinion that amid the recent sweeping depreciation of the national currency, the 2015 yearend inflation is most probably anticipated to reach a value higher than $13 \%$.

The Consumer Price Index (CPI) in the first 19 days of October gained $0.5 \%$ ( a total of $0.8 \%$ in October 2014). Monetary factors are exercising a restraining influence on inflation. Slow growth in bank lending volumes remains the key contribution to relatively slow growth rates in the monetary base.

The monetary base (broad definition) in September remained the same, running at $\mathrm{Rb} 9810.4 \mathrm{bn}$ as of the beginning of October ( $\mathrm{Rb}$ 9837.2bn as of the beginning of September). The following components of the broad monetary base saw a decline in September: the required reserves (a decrease by $25.6 \%$ to $\mathrm{Rb} 364.1 \mathrm{bn}$ ), banks' balances on correspondent accounts held with the Bank of Russia (a decrease by $12.1 \%$ to Rb $1453.8 \mathrm{bn}$ ), banks' deposits (a decrease by $3.6 \%$ to $\mathrm{Rb} 280.5 \mathrm{bn}$ ). The volume of cash in circulation, including cash balances in credit institutions, remained almost the same and amounted to $\mathrm{Rb} 7711.9 \mathrm{bn}$. The broad monetary base's growth rate in September was $-1.4 \%$ on a year-overyear basis (3.1\% up in August 2015 compared to August 2014). The key factor restraining the broad monetary base's growth was a decline in volumes of the Bank of Russia's liquidity provided to commercial banks, which was determined by a stabilized situation in the money market and a weaker demand by commercial banks for the central bank's resources denominated in rubles. The narrow monetary base (cash plus required reserves) in September decreased by $1.6 \%$ to Rb 7931.2bn (Fig. 3).

The average daily volume of reserves in commercial banks in September increased $4.1 \%$, compared to August, to $\mathrm{Rb} 1621.3 \mathrm{bn}$, and the averaged amount of reserves in the period between 10 September 2015 до 10 October 2015 amounted to Rb 1257.2bn (higher by $17.6 \%$ than the value seen in the previous period). In the period between 10 September 2015 and 10 October 2015 commercial banks' surplus reserves ${ }^{1}$ averaged $\mathrm{Rb} 385.0 \mathrm{bn}$ (lower by $1 \%$ than the value seen in the previous period), of which banks' deposits on the accounts held with the Russian central bank averaged $\mathrm{Rb} 257.3 \mathrm{bn}$, a decline of $17.4 \%$ compared to the value seen in the previous period, and correspondent accounts, less the averaged amount of reserves, in the period under review were running at an average of $\mathrm{Rb} 127.6 \mathrm{bn}$ (higher by $7.7 \%$ than the value seen in the previous period).

As of 1 October 2015, the amount of loans, deposits and other funds raised by credit institutions from

1 Commercial banks' surplus reserves held with Russia's Central Bank refer to the amount of commercial banks' deposits held with the Bank of Russia and correspondent accounts less the averaged amount of required reserves.

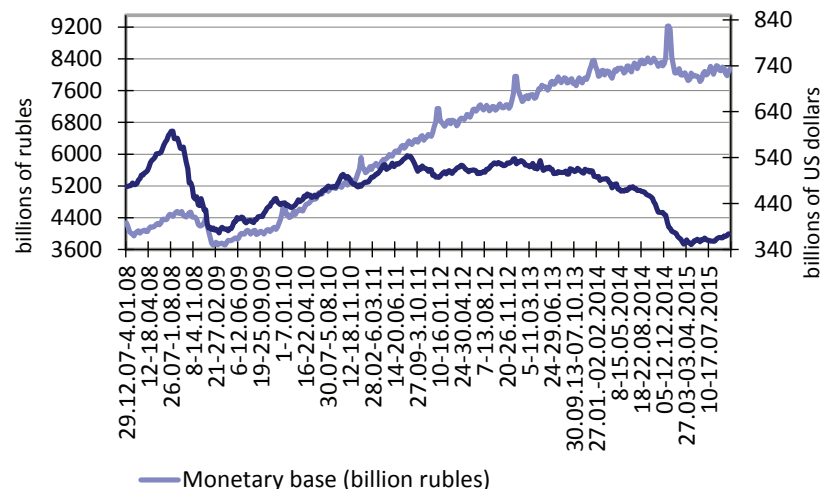

Monetary base (billion rubles)

- Gold and Foreign Currency Reserves (billion dollars)

Source: The Central Bank of Russia.

Fig. 3. The dynamics of the monetary base (narrow definition) and the Russian Federation international reserves in 2007 to 2015

the Bank of Russia reached $\mathrm{Rb} 5.8$ trillion, a decrease by $11.8 \%$ since earlier in September. Banks' debt on repos increased $13.8 \%$ to $\mathrm{Rb} 1.5$ trillion due to the tax period commencement and higher demand for rubledenominated liquidity. At the same time, debts on loans secured by non-marketable assets decreased by $10.4 \%$ to $\mathrm{Rb} 2.7$ trillion (Fig. 4). Banks' debt on repos in October remained almost the same, whereas debts on other loans decreased by $8.2 \%$ to $\mathrm{Rb} 2.4$ trillion.

In September 2015, the MIACR (Moscow InterBank Actual Credit Rate) on overnight interbank loans denominated in rubles didn't hit the interest rate band cap and stood within an average range of $11.2 \%$ (10.86\% in August 2015). In October, the interbank average lending rate was $11.1 \%$ (Fig. 5).

Banks' currency repo debt to the Russian central bank in September decreased by $10.9 \%$ to $\$ 29.4 \mathrm{bn}$ including \$26.0bn on repos for a term of one year and \$3.4bn for a term of 28 days. Due to upcoming maturities of foreign loans taken out by Russian companies and payments on annual currency repo auctions the regulator has stated that it will make decisions where necessary to refinance banks' current foreign currency debt to the Russian central bank and resume using this instrument to be able to provide currency liquidity. However, we already noted in our previous review that this instrument is not supposed to be used until financial sustainability is at risk, and in general the ruble exchange rate must keep floating to allow the economy to adapt more efficiently to changes in the terms of trade.

The Bank of Russia held on 4 September 2015 a credit auction to provide commercial banks with dollar-denominated loans secured by pledge of receivables. The Bank lent a total of $\$ 444.0 \mathrm{~m}$ at an interest rate of $2.4543 \%$ p.a. for a term of 28 days. A similar auction was held on 2 October 2015, where the Bank lent a total of $\$ 445.0 \mathrm{~m}$ at an interest rate of $2.444 \%$ p.a. for a term of 28 days. 


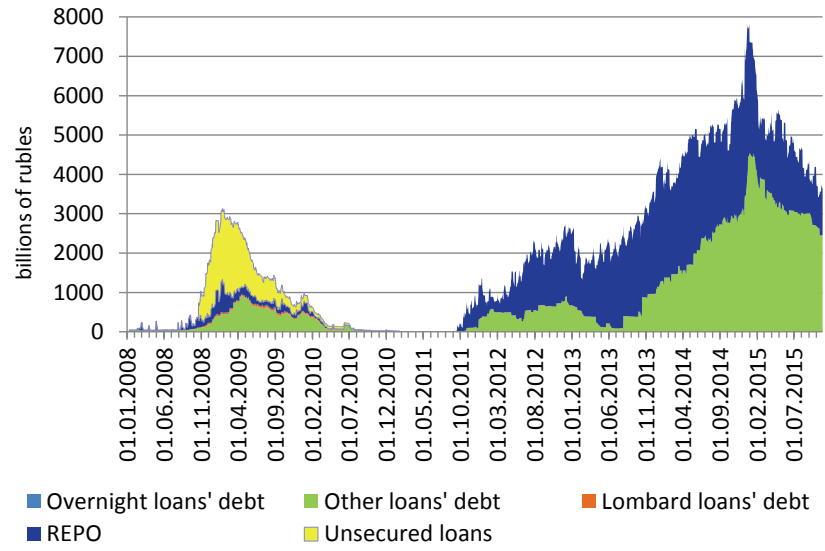

Source: The Central Bank of Russia.

Fig. 4. Commercial banks' ruble-denominated debt (in key instruments) to the Bank of Russia in 2008 to 2015

As a reminder, the Russian central bank announced on 29 July 2015 that it would not buy foreign currency to increase its international reserves. The decision was made with a view to reducing the demand for foreign currency in the market, which increased due to another fall in oil prices. As a result, the Bank of Russia performed no currency interventions in August-September 2015. In addition, the Russian central bank increased in September its international reserves from $\$ 357.6 \mathrm{bn}$ to \$366.3bn (as of 1 October 2015).

The ruble depreciated in real terms in September. The ruble's real effective exchange rate against foreign currencies weakened by $0.9 \%$ ( $11.4 \%$ down in August 2015). Overall, the ruble's real effective exchange rate in Q3 2015 decreased by $13.7 \%$ (Fig. 7).

The ruble in September gained against the US dollar by $1.5 \%$, from 66.7 rubles per US dollar to 65.7 rubles per US dollar, and the euro against the ruble lost $1.4 \%$, to 73.8 rubles per euro, and the value of the dual-currency basket decreased by $1.5 \%$, to 69.4 rubles. The ruble in October saw faster strengthening rates, e.g., in the first 28 days of October the ruble-dollar exchange rate increased $3.4 \%$ to 63.5 rubles per US dollar. The ruble gained against the euro $4.8 \%$, according to the data on 28 October. As a reminder, the sweeping depreciation of the ruble against the US dollar in August resulted in values which were higher than the record highs reached in December 2014 (67.8 rubles per US dollar on 17 December, 70.7 rubles per US dollar on 25 August), the ruble reached the value seen earlier in the year. It is the fall in oil prices that was the key factor of the ruble's depreciation (by an average of $15.3 \%$ in August 2015). It should be noted that the appreciation of the ruble in September-October was determined by improved conditions in the oil market, the tax period commencement, and also because the Fed's interest rate remained unchanged.

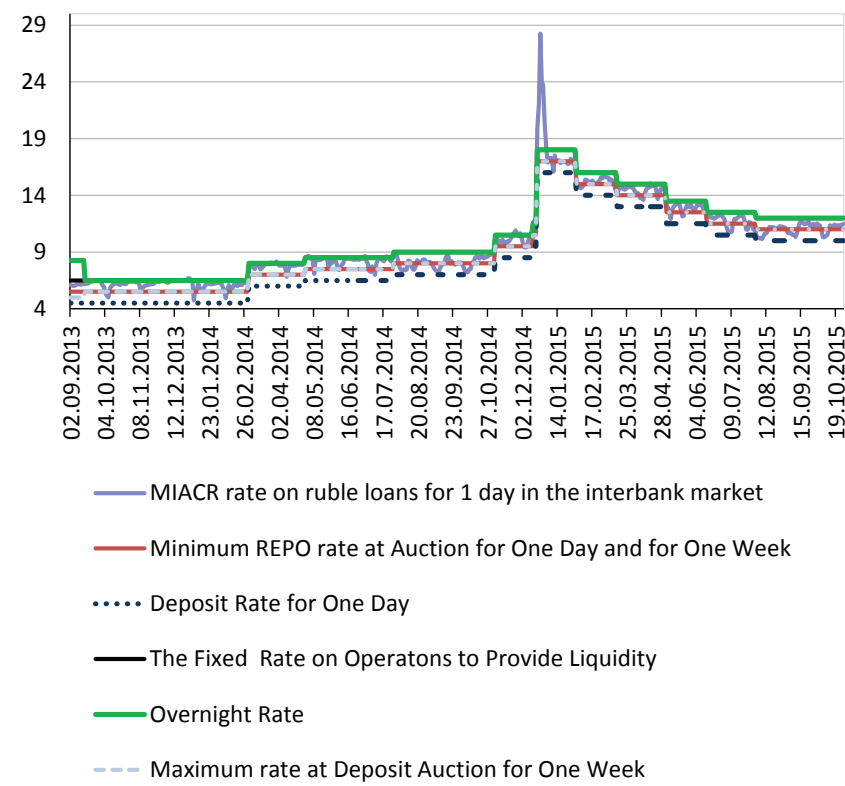

Source: The Central Bank of Russia.

Fig. 5. The Bank of Russia interest rate band and the dynamics of the interbank lending market in 2012 to 2015 (in percent per annum)

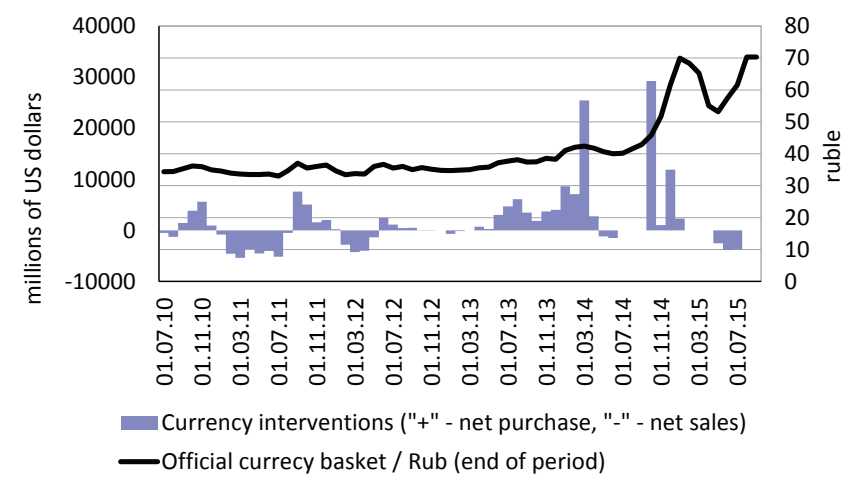

Source: The Central Bank of Russia.

Fig. 6. Bank of Russia's foreign currency interventions and the ruble exchange rate against the currency basket in March 2010 - September 2015

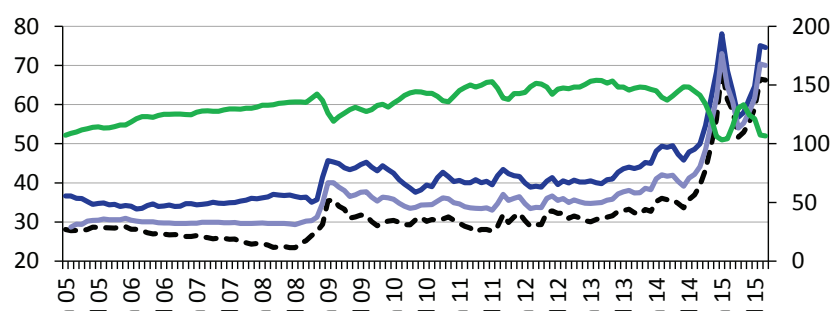

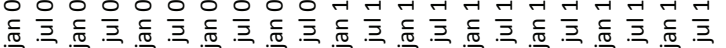

- - Official USD/RUR exchange rate (end of period)

- Official EUR/RUR exchange rate (end of period)

Value of the two-currency basket

Real effective exchange rate index (right scale)

Source: The Central Bank of Russia.

Fig. 7. Ruble exchange rate indicators in January 2005 - September 2015 